\title{
Reservoir Water Quality at Corydon, lowa
}

\author{
lowa Fact Sheet
}

\section{Introduction}

In an effort to provide the public with information concerning water resources, the U.S.Geological Survey (USGS) helps to monitor and assess water quality throughout the United States. In agricultural areas where crop production is the main land use, nonpoint-source contamination of drinking-water supplies by pesticides and fertilizers is a major concern. In lowa, herbicides such as atrazine and cyanazine commonly are used to control annual grasses and weeds, and nitrogen is applied as a nutrient for crop growth. These agrichemicals, applied to the land to maximize crop production, have been associated with the deterioration of water quality as they are transported by water into streams and reservoirs. The amount of agrichemicals in a reservoir and the effect of land-use practices within a watershed on reservoir water quality are of concern to communities that obtain water for drinking from surface-water sources such as reservoirs. In 1986, the lowa Department of Natural Resources and the University of lowa Hygienic Laboratory tested 33 lowa water supplies obtained from surface-water sources. Of the 33 water supplies tested, 21 exceeded preliminary lifetime health-advisory concentrations, as established by the U.S. Environmental Protection Agency (USEPA), for one or more pesticides. Some of the largest concentrations of commonly used herbicides were in samples of treated water from Corydon Reservoir. In an effort to assess long-term quality of water in Corydon Reservoir, data have been collected since October 1990. This fact sheet describes changes in land-use practices in the Corydon Reservoir watershed, and summarizes water-quality monitoring from October 1990 through December 1994 by the USGS in cooperation with the lowa Department of Natural Resources.

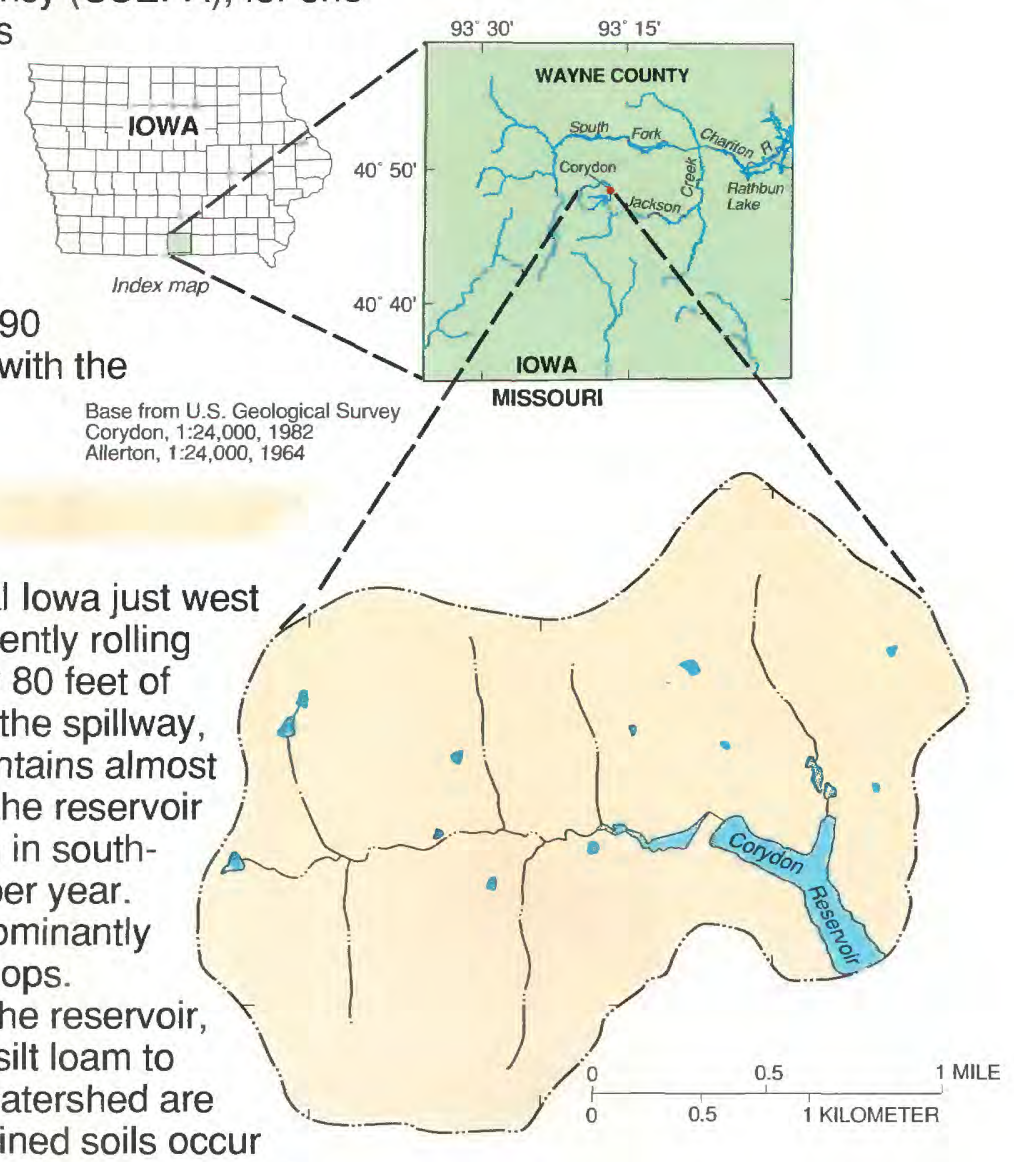

\section{Study Area}

The Corydon Reservoir watershed is in south-central lowa just west of the town of Corydon in Wayne County (fig.1). The gently rolling terrain of the 1,680-acre watershed has approximately 80 feet of relief. When the level of the reservoir is at the crest of the spillway, the reservoir covers an area of about 58 acres and contains almost 15 million cubic feet of water. The maximum depth of the reservoir is about 12 feet (fig. 2). The mean annual precipitation in southcentral lowa from 1961 to 1990 was about 36 inches per year. Land use in the Corydon Reservoir watershed is predominantly agricultural with corn and soybeans being the major crops.

Surface runoff is the main source of water inflow to the reservoir, with lesser amounts of inflow from ground water. The silt loam to silty clay loam soils of the uplands and slopes of the watershed are moderately to poorly drained, and moderately well-drained soils occur only in the intermittent stream valleys. The prevalence of poorly-drained soils and rolling topography in the watershed allows most rainfall to run off from the land surface. This extensive surface-water runoff may result in a

Figure 1. Location of the Corydon Reservoir Watershed, Wayne County, lowa water-level rise in Corydon Reservoir soon after rainfall and promote increased soil erosion. 


\section{Changes in Land Use}

Reducing the runoff of water and soil from agricultural fields into Corydon Reservoir is an important step to improving water quality and soil conservation. Agrichemicals applied to the land may dissolve in water or adhere to loose soil. During a rain, the chemicals may be transported by water to the reservoir from nearby fields.

Siltation, filling in of the reservoir with sediment, also results from surface-water runoff. The delta-like shape of the 6-foot line of equal water depth upstream from sampling site 40 (fig. 2) is evidence that siltation is occuring in Corydon Reservoir. Changes in land-use practices to reduce soil erosion, agrichemical transport, and siltation, and subsequently improve water quality in the reservoir, began in the summer of 1991. The changes in land-use practices included modifying herbicide applications, conservation tillage, and building terraces (Alan Teel, lowa State University Extension, and Douglas Bahl, U.S. Soil Conservation Service, oral commun., 1994).

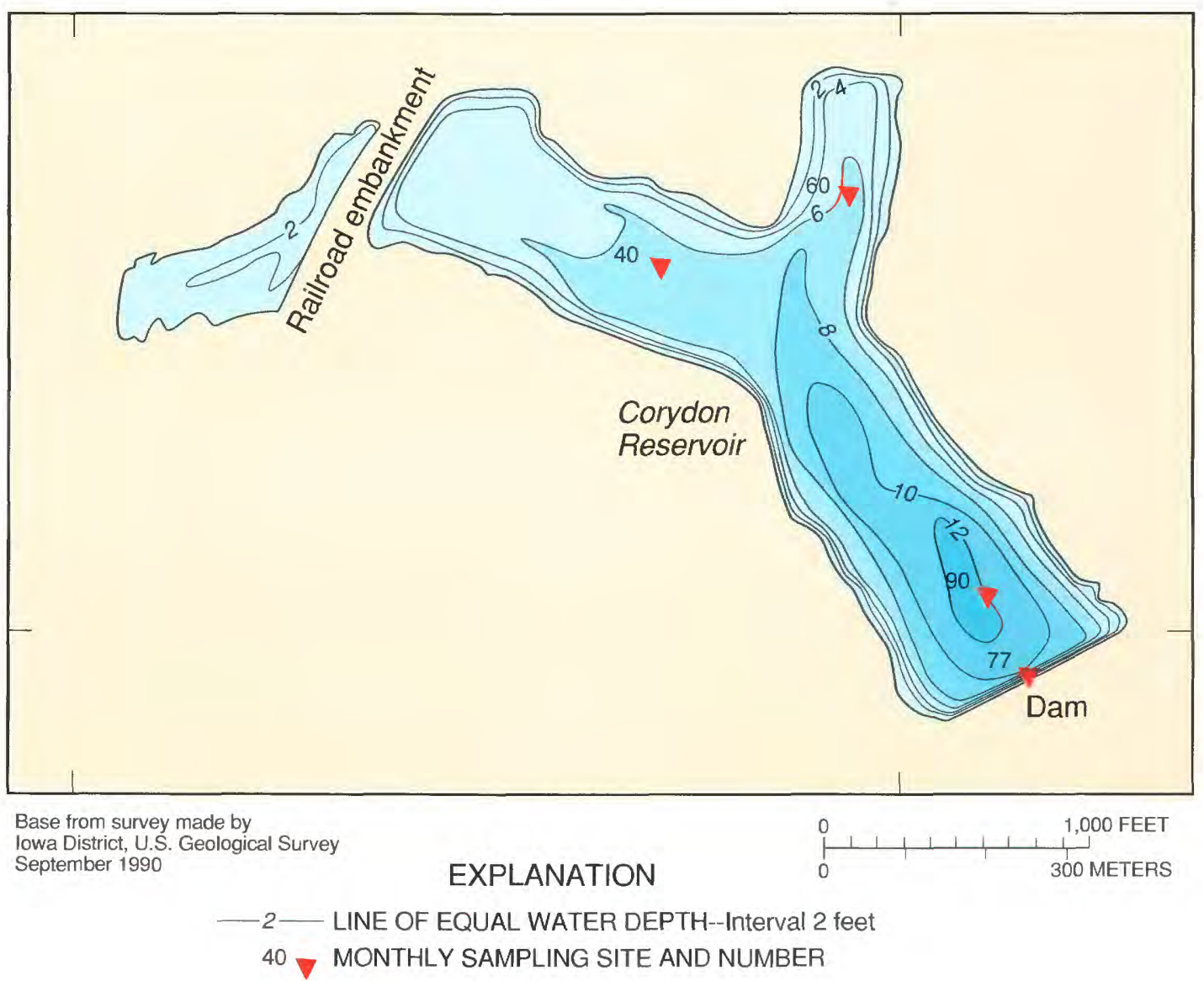

Figure 2. Water depth in Corydon Reservoir, September 1990 (modified from Kalkhoff, 1993).

\section{Water-Quality Monitoring}

The USGS has monitored the water quality at Corydon Reservoir monthly since October 1990 to help evaluate the effect of changes in land-use practices on water quality. Water quality is monitored monthly at sites $40,60,90$ and, when water is flowing over the spillway, at site 77 (fig. 2). The monitoring includes onsite measurements of specific conductance, $\mathrm{pH}$, water temperature, transparency, dissolved oxygen, coliform and streptococci fecal bacteria, and collection of water samples for laboratory analysis. The samples are shipped to the USGS laboratory in Arvada, Colorado, and analyzed for dissolved solids, nutrients, selected herbicides, organic carbon, and chlorophyll. Immunoassay analysis to detect atrazine and cyanazine in water samples is performed and gas chromatography/mass spectrometry (GC/MS) analysis is used to verify the immunoassay results and to determine concentrations of selected additional herbicides. The immunoassay results may be larger than GC/MS results since the immunoassay test may cross react with similar herbicides when analyzing for a specific herbicide. Cyanazine immunoassay analysis began in December 1992, and the atrazine immunoassay technique used prior to 1992 produced results inconsistent with GC/MS results. 


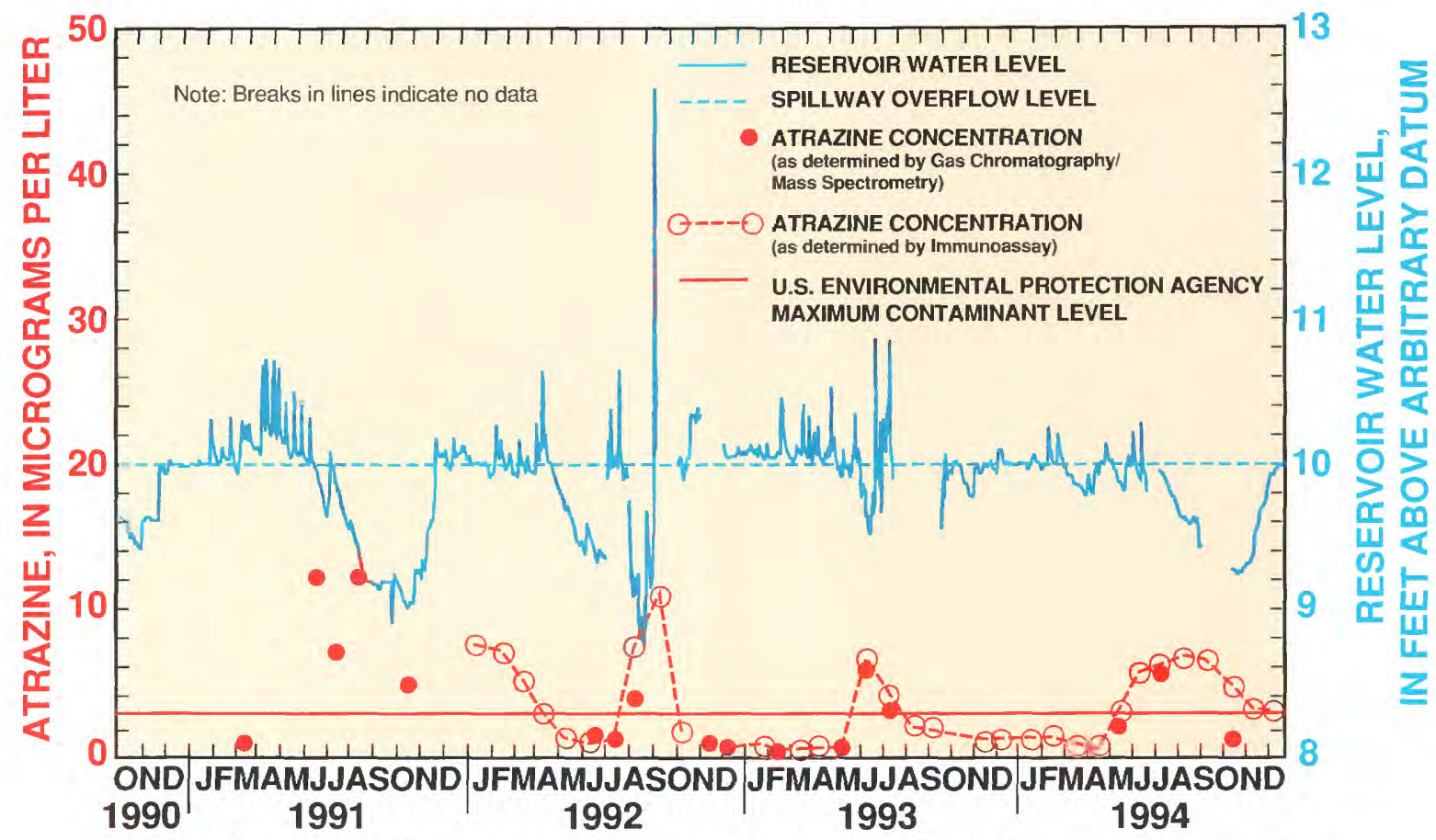

Figure 3. Average atrazine concentrations in water from selected sampling sites and reservoir water levels at Corydon Reservoir, October 1990 through December 1994.

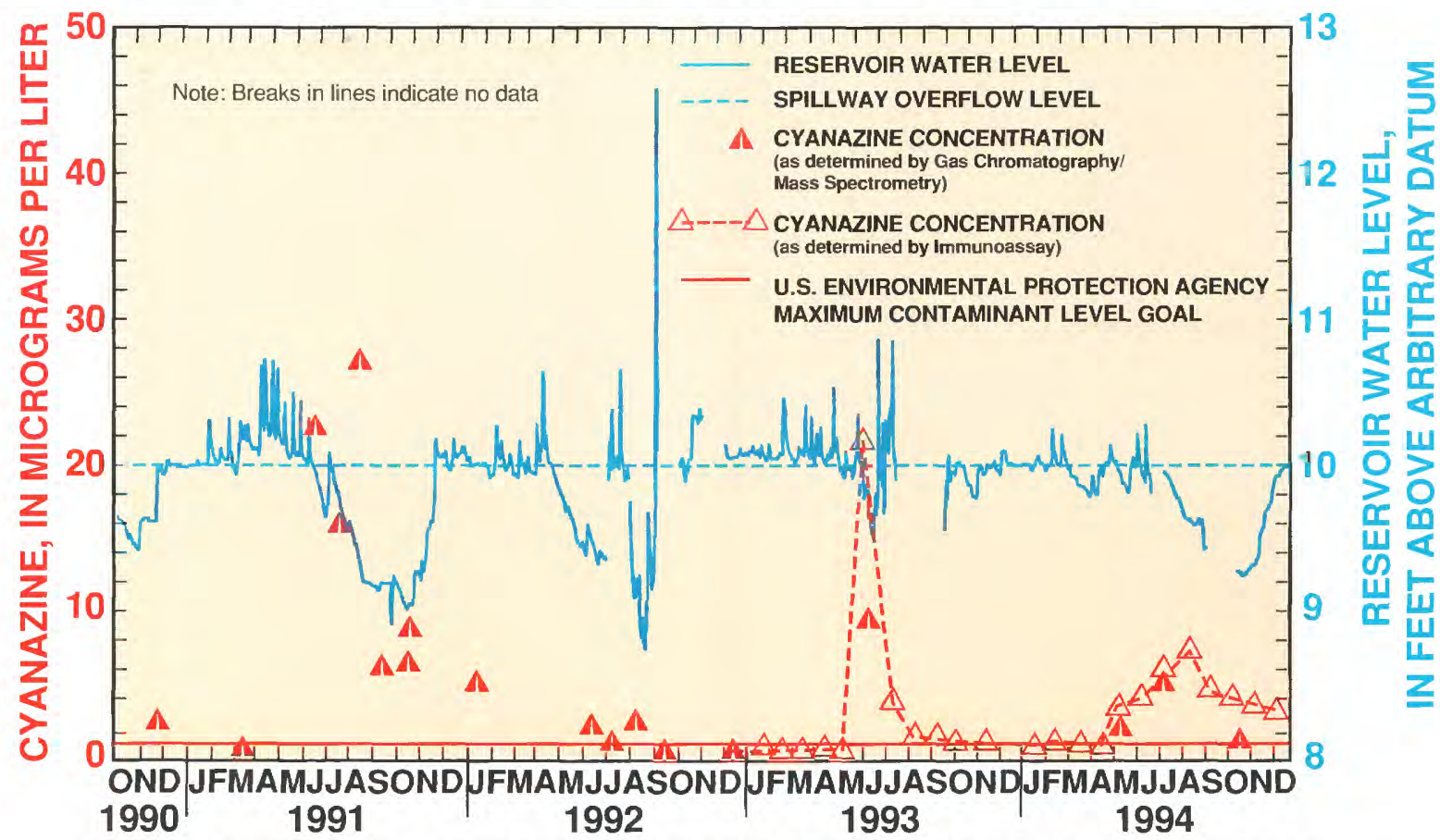

Figure 4. Average cyanazine concentrations in water from selected sampling sites and reservoir water levels at Corydon Reservoir, October 1990 through December 1994.

Adverse health effects may occur if water with herbicide concentrations exceeding drinking water regulations is consumed over an extended period of time. The USEPA has established enforceable Maximum Contaminant Levels (MCL) and nonenforceable Maximum Contaminant Level Goals (MCLG) for various chemicals in drinking water to protect human health. The MCL for atrazine is 3.0 micrograms per liter $(\mu \mathrm{g} / \mathrm{L})$, or parts per billion, and the MCLG for cyanazine is $1.0 \mu \mathrm{g} / \mathrm{L}$. Atrazine and cyanazine concentrations found in the water from Corydon Reservoir are summarized in figures 3 and 4 and represent averages of the herbicide concentrations in water from all sampling sites for each month. Concentrations tend to be largest in the late spring and summer after herbicide application. Atrazine and cyanazine concentrations appear to persist in the reservoir until rainfall runoff raises the reservoir level above a gage height of 10 feet, the level at which water flows over the spillway, transporting the herbicides downstream, or until degradation of the herbicides occurs. 


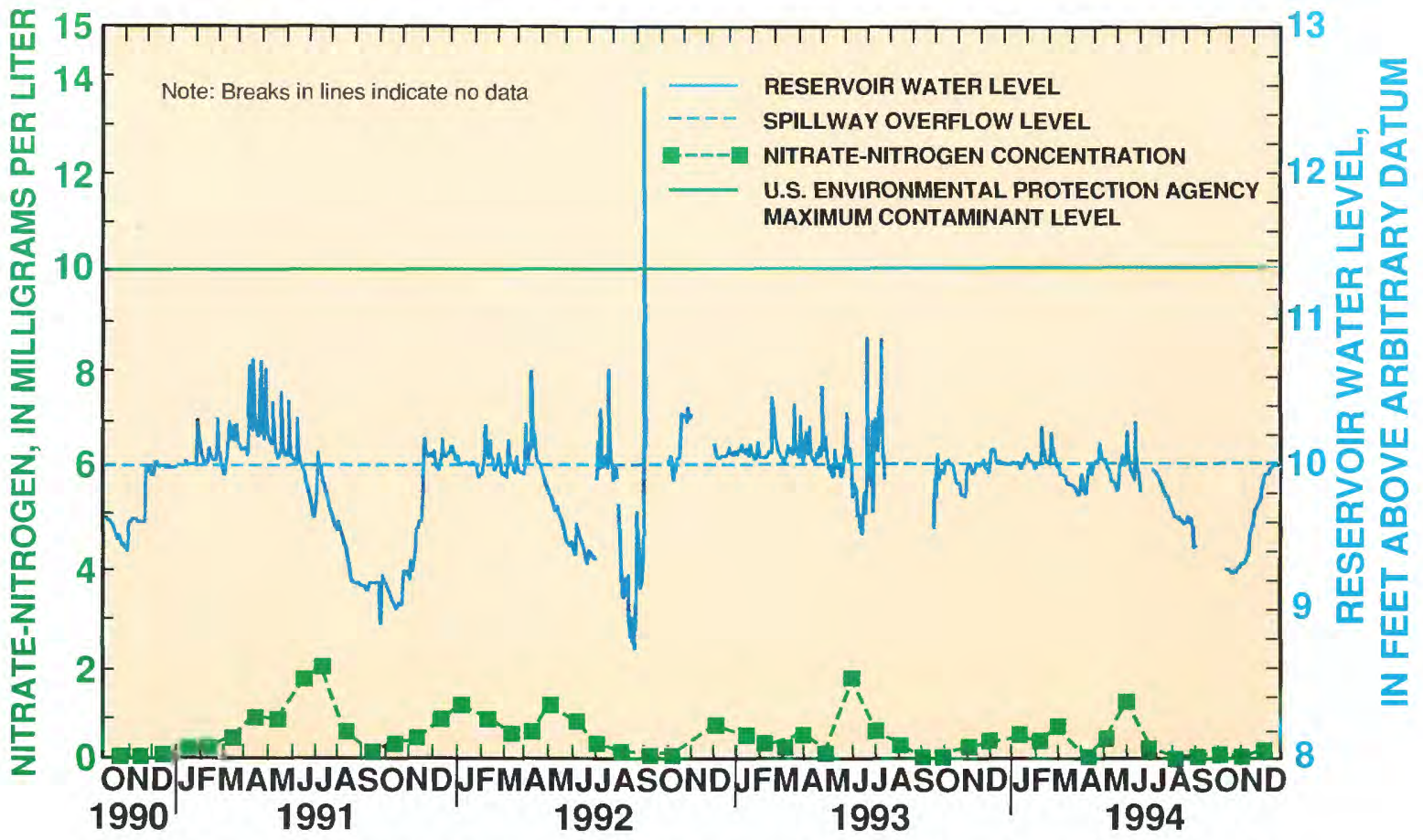

Flgure 5. Average nitrate-nitrogen concentrations in water from selected sampling sites and reservoir water levels at Corydon Reservoir, October 1990 through December 1994.

Large nitrate-nitrogen concentrations also are a health concern; USEPA has established an MCL for drinking water of 10 milligrams per liter $(\mathrm{mg} / \mathrm{L})$. Concentrations of nitrate-nitrogen resulting from agrichemical runoff are generally largest in May, June, or July after spring fertilizer application. Nitrate-nitrogen concentrations in Corydon Reservoir for October 1990 through December 1994 were considerably less than the $10 \mathrm{mg} / \mathrm{L} \mathrm{MCL}$ (fig. 5).

Protection of reservoir water quality is important because many communities in lowa use reservoirs for drinking-water supplies. Monitoring of water quality at Corydon Reservoir is helping to document how changes in land-conservation and agricultural practices affects reservoir water quality and the future of Corydon Reservoir as a potable water source.

-Matthew W. Bobier

\section{Additional Reading}

Kalkhoff, S.J.,1993, Water quality of Corydon Reservoir before implementation of agricultural best-management practices in the basin, Wayne County, lowa, September 1990 to September, 1991: U.S. Geological Survey Water Resources Investigations Report 93-4099, $36 \mathrm{p}$.

Miller, J.G..,and Kennedy, J.O., 1991, lowa Lakes study: lowa City, University of lowa Hygienic Laboratory Report No. $91-3,69$ p.

Lockridge, L.D., 1971, Soil survey of Wayne County, lowa: U.S. Department of Agriculture, Soil Conservation Service, 86 p.

National Oceanic and Atmospheric Administration, 1994, Climatological data lowa: U.S. Department of Commerce, v. 103, no.13, 44 p.

U.S. Environmental Protection Agency, 1989, Health Advisories Summaries: Office of Drinking Water, Washington, D.C., 2 p. 1993, Drinking water regulations and health advisories; Washington, D.C., Office of Drinking Water, 11 p.

Wnuk, Monica, Kelly, Richard, Breuer, George, and Johnson, Lauren, 1987, Pesticides in water supplies using surface-water sources: Des Moines, lowa Department of Natural Resources, 33 p.

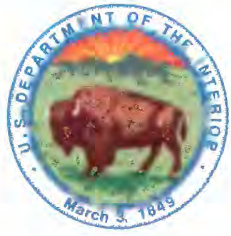

July, 1995
For more information, please contact:

District Chief

U.S. Geological Survey

Post Office Box 1230

Federal Building, Room 269

400 South Clinton Street

lowa City, lowa 52240

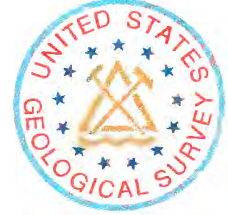

FS 95-119 